\title{
Social Identity and Use of Taboo Words in Angry Mood: A Gender Study
}

\author{
Mohammad Hashamdar \\ Department of English Language Teaching, Karaj Branch, Islamic Azad University, Karaj, Iran \\ Fahimeh Rafi \\ Karaj Branch, Islamic Azad University, Karaj, Iran
}

\begin{abstract}
The aim of the present study was to investigate the relationship between social identity and the taboo words men and women use in order to express their anger. Moreover, this study went further and investigated the relationship between using taboo words in male and female participants who had a university degree and those who did not. In order to do the research, 20 female and 20 male adults, whose professions were similar in pairs, were randomly selected. The researcher recorded their voices when they were in an angry mood. After recording data, the researcher made a transcription of the first fifty words uttered by each participant. Then, the taboo words- words which were considered offensive or shocking and that were discouraged in public places - were calculated. Finally, the percentage of taboo words used by each participant was calculated and compared to that of the others. The findings of the study confirmed that the percentage of using taboo language by male characters, in different social identities, was much more than that of female characters. On the other hand, by dividing the participants into two groups of those who had a university degree, and those with no university degree, the researcher came to the conclusion that both male and female participants with a university degree used less taboo words than those without a university degree.
\end{abstract}

Index Terms — curse, gender, sex, social identity, swearing, taboo language

\section{INTRODUCTION}

One of the most important issues in sociolinguistics is the relationship between linguistic features, social roles and identities of the men and women who speak these languages. Gender difference in language learning and language use is an interesting subject for researchers to work on. Scholars have done variety of research to see if there are any differences between the way men and women learn or use language. And if there are such differences, what are the reasons for them? On the other hand, linguistic taboos also exist in most cultures and languages. Taboo words are usually culture-specific; and are generally avoided and considered inappropriate. Moreover, human beings normally live in a community. Human beings use language in order to communicate with each other, in other words, language is a particular system of human communication (Richards \& Schmidt, 2010). People communicate with each other in communities or in social contexts. People use language in order to convey information, feelings, attitudes, or make a kind of identity in real world. But the most important fact is that all these factors are just meaningful in social life. Therefore, it seems interesting to study the relationship among language, society, social life, identity, gender, and also using taboo language.

\section{A. Language and Socialization}

"Language is understood as a part of the social system, language is a socialization process, and language is constrained by the Socialization process" (Fairclough, 1989, p.22). From this perspective, language functions within a social system and cannot be separated from the social functions that it creates (Bakhtin, 1981; Fairclough, 1989; Halliday, 1978; Lemke, 1995).

Language cannot exist outside the society, it can just have meaning when placed within its social context. In other words, language permeates social life. Thus, it is comprehensible that language cannot occur in isolation but can only happen within the social system. Spolsky (2010) believed that one of the most common ways to identify different people is by their languages, because languages are involved in socialization.

Halliday(1978) explained that "a social theory of language looks at language in terms of how it functions within a set of relational contexts. When people learn language they are learning not only the structural or linguistic system, but also how much meaning is relational to the social order and social situation" (p.18). Lemke (1995) and (2000) also considered language use as a behavior which is socially and culturally meaningful, that is, when people use language, they reveal their social and cultural stances within the social context. Therefore, we can clearly say that language is a vehicle for conveying social and cultural information.

\section{B. Language and Social Identity}


Kroskrity (2000) defined 'identity' as the linguistic construction of membership in one or more social context. 'Identities' are the characteristics, social relations and roles that define who one is. Wardhaugh \& Fuller (2015) proposed when people speak, they use some words, expressions, grammatical structures, etc. that can transmit some information concerning their gender, age, social class, cultural status, socioeconomic status, background, and so on. Thus, the way we speak is related to the kind of person we are. Bradac (1990) and Giles \& Street (1994) believed that listeners can easily infer speakers' characteristics from the language they use. On the other hand, Wardhaugh and Fuller (2015) also believed that identity is not something you have, it is something you do, and it is created in interactions. They also added that identities are fluid and there is not just one single identity but multiple levels of identity which emerge in different contexts. That is, "we may identify as similar to a person in one situation, and as different in another" (p. 73). In other words, "identities are not fixed attributes of people or groups but are dynamically constructed aspects which emerge through discourse and social behavior" (p. 7). Ochs (1993) also stated the same idea by saying that social identity and language behavior do not always fit each other. That is, people belonging to the same social identity hardly use the same linguistic structures at all. Ochs (1993) added that "speakers may shift their acts and stances many times and, in so doing, reconfigure the social identities of themselves and others over a brief period of time. Social identities evolve in the course of social interaction, transformed in response to the acts and stances of other interlocutors as well as to fluctuations in how a speaker decides to participate in the activity at hand" (p. 298). Baxter (2002) also believed that speakers' identities are not fixed, they are continually reconstructed and redefined through discourse; that is, they cannot exist outside of discourse. Bucholtz and Hall (2005) proposed that identity cannot be considered as the source but the outcome of linguistic practice. Bruner (1990) also suggested that the symbolic systems that individuals use in constructing meanings are deeply entrenched in culture and language.

Tajfel (1978) distinguished between two different types of identities which can be named as personal identities and group identities. When personal identities are the basis for an interaction, our behavior will be subject to more variability. But when the basis for an interaction is group identity, the way we behave and talk will tend to accentuate uniformity (cited in Meyerhoff, 2011).

Social identity relates to the way we try to identify ourselves in relation to others. Of course, social identities are not simply labels that we fill with our own intentions, but labels or images which are created by other group members (Wardhaugh and Fuller, 2015). Hogg-and Vaughan (2002) also claimed that social identity is derived from one's perceived membership in social groups. Social identity can provide people with a sense of self-esteem and a framework for socializing, and it can influence their behavior. Ochs (1993) defined social identity "as a cover term for a range of social personae, including social statuses, roles, positions, relationships, and institutional and other relevant community identities one may attempt to claim or assign in the course of social life" (p.288).

\section{Language and Gender}

Wardhaugh and Fuller (2015) distinguished between sex and gender. They stated that sex categories are based on the biological distinction (male \& female), while gender is culturally constructed, that is, gender talks about the cultural traits and behaviors seem to be appropriate for men and women by a particular society. Sex is a concrete, binary concept but gender is a continuum.

Trudgill (2000) believed that language is a social phenomenon which is related to social attitudes. Men and women are also socially different so they are expected to have different social roles and also different behavior patterns. On the other hand, these differences are reflected in the language they use, too. That is, the speech patterns used by men and women are completely different. Different scholars suggested variety of differences between men's and women's speech pattern. For example, Meyerhoff (2006) proposed that women use the standard language and also incoming variant more than men. On the other hand, Lakoff (2004) stated that women use more indirect requests and euphemisms, they use more polite words, and they try to avoid strong swear words. Moreover, Tannen (1992) proposed that difference in men's and women's speech pattern is a matter of what language means to them. For women, speech is a way of creating connection and solidarity; while for men, it is a way to preserve independence and maintain status in a hierarchical social order. Scholars have finally come to the conclusion that women's and men's speech patterns are syntactically, semantically, phonologically, and morphologically different.

\section{Gender and Taboo Language}

Richards \& Schmidt (2010) and also Trudgill (2000) defined taboo language as words and expressions that are offensive or embarrassing and that are discouraged in public usage. Based on the preceding definition, insults, swearing, oaths, curses and the like are all considered as taboo words. Wardhaugh (1984) explained the idea more generally, "taboo is one way in which a society expresses its disapproval of certain kinds of behavior believed to be harmful to its members, either for supernatural reasons or because such behavior is held to violate a moral code" (p. 45).

Jay (1999) believed that men use more taboo words and offensive curse words than do women. Coates (2004) also supported the idea and added that "men and women use taboo language differently. In daily life, men tend to use more taboo words compared to women. The belief that women's language is more polite, more refined - in a word, more ladylike - is very widespread and has been current for many centuries" (p. 13). Gomm (1981) stated that both men and women use swear words more in the company of their own sex; but the usage drops dramatically in mixed-sex conversations. (cited in Coates, 2004). 
Considering the aforementioned opinions and researches, there is no doubt that most men and women with different identities use taboo words. But the question that the researcher is going to answer, concerns the difference in frequency of taboo words used by male and female characters in different social identities and different educational level, when they are in an angry mood.

\section{E. Research Questions}

The questions which are posed in this study are as follows:

1. Is there any relationship between social identity and use of taboo words in female and male adult speakers, when they feel angry?

2. Is there any difference in frequency of taboo words used by female characters who have a university degree and those who do not, when they are in an angry mood?

3. Is there any difference in frequency of taboo words used by male characters who have a university degree and those who do not, when they are in an angry mood?

\section{METHODOLOGY}

\section{A. Participants}

In order to do the present research, 20 female adults and 20 male adults, whose professions were similar in pairs, were randomly selected. That is, there were, for example, two mechanical engineers, one a woman and the other a man. The participants were all within the age range of 20-45. Moreover, this research was done in Zanjan and the participants were all bilingual speakers who could speak Persian and Turkish fluently. The participants' occupations can be listed as follows:

primary school teacher, high school teacher, electrical engineer, university student at M.A. level, university instructor, taxi driver, dentist, specialist, nurse, shopkeeper, business person, cook, worker, architect, lawyer, designer, translator, hairdresser/barber, bank clerk.

As it is obvious, the researcher tried to select participants with variety of social identities in order to come to an accurate and precise conclusion about the relationship between males' and females' social identity and their use of taboo words when they feel angry.

\section{B. Instruments}

The researcher used her cell phone to record the participants' voices while they were speaking angrily in different occasions. There were no papers or questionnaires to be given to the participants. They were not even informed about the research or about recording their voices. Of course, the researcher was determined not to use or mention the participants' names for the sake of their privacy; so all through the procedure of the research these participants were named by numbers and letters. For example, participant number $1 \mathrm{~A}$ was the female university instructor, and participant number $1 \mathrm{~B}$ was the male university instructor. Letter A was considered for all the female participants, and letter B for the male participants. After collecting the recorded data, the researcher made a transcription of the sentences uttered. Then, the researcher counted the taboo words and calculated the percentage of using taboo words for each individual participant; and finally the results were compared.

\section{Procedure}

First, the researcher randomly selected 20 female and 20 male participants whose occupations or social identities were similar in pairs. Then, the researcher recorded participants' voices, when they were in an angry mood. After collecting the recorded data, the researcher made a transcription of the first fifty words used by each participant in order to be able to analyze and compare them in detail. Then, the taboo words used by each participant were calculated. Finally, the percentage of using taboo words for each participant was computed and compared to that of the others. The researcher was willing to see if there were any differences in the number of taboo words used by male and female characters in different social identity categories and different educational level, when they were in an angry mood.

\section{RESULTS}

After recording and transcribing the participants' voices, the taboo words used by each participant in the first fifty words they had uttered, were counted and noted down. It is necessary to be mentioned that the researcher followed Richards' \& Schmidt's (2010) and also Trudgill's (2000) definition of taboo language in order to do the research. That is, all the words and expressions that were offensive or embarrassing and that were discouraged in public usage were considered as taboo language. Table 1. shows the results of the study in detail. 
TABLE 1.

PERCENTAGE OF TABOO WORDS USED BY THE TwO GROUPS

\begin{tabular}{|l|l|l|}
\hline \multirow{2}{*}{ PARTICIPANTS } & \multicolumn{2}{|l|}{ PERCENTAGE OF TABOO WORDS } \\
\cline { 2 - 3 } & Female(A) & Male(B) \\
\hline primary school teacher & $12 \%$ & $18 \%$ \\
high school teacher & $8 \%$ & $18 \%$ \\
electrical engineer & $4 \%$ & $10 \%$ \\
university students at M.A. level & $28 \%$ & $28 \%$ \\
Ph.D. candidate & $12 \%$ & $6 \%$ \\
university instructor & $6 \%$ & $8 \%$ \\
taxi driver & $36 \%$ & $30 \%$ \\
dentist & $6 \%$ & $10 \%$ \\
specialist & $6 \%$ & $8 \%$ \\
nurse & $22 \%$ & $36 \%$ \\
shopkeeper & $22 \%$ & $28 \%$ \\
business person & $16 \%$ & $30 \%$ \\
cook & $28 \%$ & $36 \%$ \\
worker & $24 \%$ & $55 \%$ \\
architect & $8 \%$ & $8 \%$ \\
lawyer & $6 \%$ & $8 \%$ \\
designer & $8 \%$ & $12 \%$ \\
translator & $6 \%$ & $10 \%$ \\
hairdresser/barber & $14 \%$ & $7 \%$ \\
bank clerk & $4 \%$ & $7 \%$ \\
\hline AVERAGE & $\mathbf{1 3 . 8 \%}$ & $\mathbf{1 8 . 6 5 \%}$ \\
\hline
\end{tabular}

Table 1 reveals three different facts:

1. It confirms that both men and women in different social identities use taboo words when they are in an angry mood.

2. It also indicates that when men, in variety of social identity categories, get angry, they mostly use more taboo words than women $($ Female $=13.8 \%$; male $=18.65 \%)$.

3. By paying close attention to each social identity category, we come to the conclusion that in most cases (there are also a few exceptions) the male participant uses more taboo words than the female participant.

TABLE 2.

PERCENTAGE OF TABOO WORDS USED BY THE PARTICIPANTS WITH NO UNIVERSITY DEGREE
\begin{tabular}{|l|l|l|}
\hline Participants with a university degree & FEMALE(A) & MALE(B) \\
\hline primary school teacher & $12 \%$ & $18 \%$ \\
taxi driver & $36 \%$ & $30 \%$ \\
shopkeeper & $22 \%$ & $28 \%$ \\
business person & $16 \%$ & $30 \%$ \\
cook & $28 \%$ & $36 \%$ \\
worker & $24 \%$ & $55 \%$ \\
designer & $8 \%$ & $12 \%$ \\
hairdresser/barber & $14 \%$ & $7 \%$ \\
\hline AVERAGE & $\mathbf{2 0 \%}$ & $\mathbf{2 7 \%}$ \\
\hline
\end{tabular}

TABLE 3.

PERCENTAGE OF TABOO WORDS USED BY THE PARTICIPANTS WITH A UNIVERSITY DEGREE

\begin{tabular}{|l|l|l|}
\hline Participants with a university degree & FEMALE(A) & MALE(B) \\
\hline high school teacher & $8 \%$ & $18 \%$ \\
electrical engineer & $4 \%$ & $10 \%$ \\
university students at M.A. level & $28 \%$ & $28 \%$ \\
Ph.D. candidate & $12 \%$ & $6 \%$ \\
university instructor & $6 \%$ & $8 \%$ \\
dentist & $6 \%$ & $10 \%$ \\
specialist & $6 \%$ & $8 \%$ \\
nurse & $22 \%$ & $36 \%$ \\
architect & $8 \%$ & $8 \%$ \\
lawyer & $6 \%$ & $8 \%$ \\
translator & $6 \%$ & $10 \%$ \\
bank clerk & $4 \%$ & $7 \%$ \\
\hline AVERAGE & $\mathbf{9 . 6 6 \%}$ & $\mathbf{1 3 . 0 3 \%}$ \\
\hline
\end{tabular}

Tables 2 and 3 have made a distinction between using taboo language, in the participants (in angry mood) who had a university degree and those who did not. These two tables clearly show the following:

1. The male participants in both groups, while furious, use more taboo words than the female participants (Females: $20 \%$ \& 9.66\%; Males: $27 \%$ \& $13.03 \%$ )

2. Comparing the female participants in both groups, we notice that the female participants who have a university degree use less taboo words than those with no university degree, even if they are in an angry mood (20\% \& 9.66\%). 
3. Comparing the male participants in both groups, we notice that the male participants who have a university degree use less taboo words than those with no university degree, even if they are in a furious mood $(27 \%$ \& $13.03 \%)$.

To sum up, the findings in this study confirms that both men and women use taboo language when they are in an angry mood. But, as it was expected, the percentage of using taboo language in male characters is much more than that of female characters. On the other hand, by dividing the participants into two groups of those who have a university degree, and those without a university degree, we come to the conclusion that both male and female participants with a university degree use less taboo words than those without a university degree.

\section{DisCUSSION}

The current study was designed to investigate the relationship between social identity and use of taboo language, by male and female characters when they are angry. In other words, this study aimed at quantifying the use of taboo words by men and female when they are in an angry mood. By taboo language, the researcher means using insults, swearing words, derogatory words, curses, slangs, dirty words, and so on which are considered offensive or shocking and that were discouraged in public usage. The research questions, first focus on the relationship between social identity and number of taboo words used by male and female characters when they feel angry; second, focus on the quantitative difference between using taboo words by female characters who have a university degree and those who do not, when they are in an angry mood; and third, focus on the difference in frequency of taboo words used by male characters who have a university degree and those who do not, when they are angry. The findings of the study proved that, in an angry mood, men in different identities use more taboo words than women. Moreover, the findings clearly showed that male and female participants with a university degree use less taboo words than those with no university degree, even when they feel angry. Therefore, the results of this study prove a noticeable relationship between social identity and use of taboo words even in angry mood. Several studies have been conducted on the differences between using taboo language in male and female characters, but there are a few studies on the impact of education on using taboo words by angry people.

The result of the present study was consistent with Coates' research (2004) which showed that women use less taboo language than men do. Coates pointed out women are more polite, indirect and collaborative in conversation; on the other hand, men are more impolite, direct and competitive. The finding in this study was also in line with Spears' (1992) which proved that using taboo language is a specialty of men rather than women.

In accordance with the current study, Trudgill (1974) and Lakoff (1975) also claimed that women use more formal language and polite forms than men (cited in Stapleton, 2003). On the other hand, Stapleton (2003), Baroni and D'Urso (1984), Romanie (1984), Spender (1980), Crosby and Nyquist (1977), Lakoff (1973), Trudgill (1972), and Milward (1937) have also claimed that men use swearing words noticeably more than women; in other words, women concerns more about politeness than men.

The finding in this study is in contradiction to Risch's study (1987), on the use of taboo words by men and women, which provided counterevidence based on data obtained in the United States. De Klerk (1992) also did a research in South Africa and strongly supported Risch's findings and "challenged the assumption that women stick to standard speech" (De Klerk, 1992). De Klerk's study rejected the idea that males use more or taboo words than women.

\section{CONCLUSION}

The primary aim of this research was to investigate the relationship between social identity and use of taboo language by female and male characters, when they are in angry mood. First, two groups of male and female participants whose social identities were similar in pairs were randomly selected. Then, the researcher recorded participants' voices, when they were in an angry mood. After collecting the recorded data, the researcher made a transcription of the first fifty words used by each participant. Finally, the percentage of taboo words- words which were considered offensive or shocking and that were discouraged in public places - used by each participant was calculated and compared to that of the others. The findings of the study proved that men, in different social identity groups, use more taboo words than women. Moreover, both male and female participants with a university degree used less taboo words than those without a university degree. Therefore, the results of the study showed a clear relationship between social identity and use of taboo words.

\section{Suggestions for Further Research}

Further research can be done to answer some issues which could not be investigated in this study. First, the number of participants in this study was 40 altogether; other studies can be done with greater number of participants. Second, the age range of the participants in this study was 20-45; further studies can be done with children or teenagers. Third, this study was done in Zanjan; other studies can be done in other cities or even countries. Fourth, this study estimated the frequency of taboo words used by the participants; further studies can be done to work on different categories of taboo words, not just their frequencies.

\section{REFERENCES}

[1] Bakhtin, M. M. (1981). The dialogic imagination. Austin, TX: University of Texas Press. 
[2] Baroni, M. R., \& D'Urso, V. (1984). Some experimental Findings about the question of politeness and women's speech. Language in Society 13:67-72.

[3] Baxter, J. (2002). Competing discourses in the classroom: A post-structuralist discourse analysis of girls' and boys' speech in public contexts. Discourse and Society, 13 (6): 827-42.

[4] Bruner, J. (1990). Acts of meaning. Cambridge, MA: Harvard University Press.

[5] Bradac, J. J. (1990). Language attitudes and impression formation. In H. Giles \& W. P. Robinson (Eds.), Handbook of language and social psychology (pp. 387-412). New York: John Wiley.

[6] Bucholtz, M. \& Hall, K. (2005). Identity and interaction: A sociocultural linguistic approach. Discourse Studies, 7(4-5): 585614.

[7] Coates, J. (2004). Women, Men and Language ( $3^{\text {rd }}$ ed.). London: Pearson ESL.

[8] Crosby, F., \& Nyquist, L. (1977). The female register: An empirical study of Lakoff's hypotheses. Language in Society 6:31322.

[9] De Klerk, V. (1992). How taboo are taboo words for girls? Language in Society 21, 277-289.

[10] Fairclough, N. (1989). Language and power. New York: Longman.

[11] Giles, H., \& Street, R. L. J. (1994). Communicator characteristics and behavior. In M. L. Knapp \& G. R. Miller (Eds.), Handbook of interpersonal communication (2 ed., pp. 103-161). Thousand Oaks, CA: Sage.

[12] Halliday, M. A. K. (1978). Language as social semiotic. London: Edward Arnold.

[13] Hogg, M. A. \& Vaughan, G. M. (2002). Social psychology (3rd ed.). London: Prentice Hall.

[14] Jay, T. (1996). What to do when your students talk dirty. Atrium Publishers Group.

[15] Kroskrity, P. (2000). Identity. Journal of Linguistic Anthropology, 9(1-2):111.

[16] Lakoff, R. (1973). Language and woman's place. Language in Society 2:45-80.

[17] Lakoff, R. (2004). Language and woman's place: Text and commentaries. London: Oxford University Press.

[18] Lemke, J. L. (1995). Textual politics: Discourse and social dynamics. London: Taylor \& Francis.

[19] Lemke, J. L. (2000). Learning academic language identities: Multiple timescales in the social ecology of education. Paper presented at the workshop on Language Socialization, Language Acquisition : Ecological Perspectives at University of California, Berkeley. Retrieved on February 25, 2010 from http ://academic.brooklyn.cuny.edu/education/ jlemke/ papers/ UCB\% 20Language \%20Socialization.htm.

[20] Meyerhoff, M. (2006). Introducing sociolinguistics. USA \& Canada: Routledge.

[21] Meyerhoff, M. (2011). Introducing sociolinguistics ( $2^{\text {nd }}$ ed.). New York: Routledge.

[22] Milward, D. (1937). The origin and development of the slang in use among the women students in the University of Cape Town in the year 1937- Unpublished Master's thesis, University of Cape Town.

[23] Ochs, E. (1993). Constructing social identity: A language socialization perspective. Research on Language and Social Interaction, 26(3), 287-306.

[24] Richards, J. C. \& Schmidt, R. (2010). Dictionary of language teaching and applied linguistics (4 ${ }^{\text {th }}$ ed.). UK: Pearson Education Limited.

[25] Risch, B. (1987). Women's derogatory terms for men: That's right, dirty words. Language in Society 16:353-58.

[26] Romaine, S. (1984). The language of children and adolescents. Oxford: Blackwell.

[27] Spears, R. A. (1992). Forbidden American English: A series compilation of taboo American English. Illinois USA: Passport Books.

[28] Spender, D. (1980). Manmade language. London: Routledge \& Kegan Paul.

[29] Spolsky, B. (2010). Sociolinguistics. Oxford: Oxford University Press.

[30] Stapleton, K. (2003). Gender and swearing: A community practice. Woman and Language 26(2), pp. 22-33.

[31] Tannen, D. (1992). You Just Don't Understand. London:Virago Press.

[32] Trudgill, P. (1972). Sex, covert prestige, and linguistic change in the urban British English of Norwich. Language in Society 1:179-95.

[33] Trudgill, P. (2000). Sociolinguistics: An introduction to language and society (4 ${ }^{\text {th }}$ Ed.). London: Penguin.

[34] Wardhaugh. R. (1984). An introduction to sociolinguistics. Oxford: Basil Blackwell.

[35] Wardhaugh, R. \& Fuller, J. M. (2015). An introduction to sociolinguistics (7 $7^{\text {th }}$ ed.). UK: John Wiley \& Sons, Inc.

Mohammad Hashamdar is a $\mathrm{PhD}$ holder in teaching English as a foreign language and a faculty member of English teaching department at Islamic Azad University of Karaj, Karaj, Iran. His academic contribution to the field of language teaching has benefited many graduate and post graduate students.

Fahimeh Rafi is a Ph.D. candidate in teaching English as a foreign language at Islamic Azad university of Karaj, Iran. She is also a faculty member of English teaching department at Islamic Azad University of Zanjan, Iran. 